\title{
Quality of cocaine seized in 1997 in the street-drug market of São Paulo city, Brazil
}

\author{
Débora Gonçalves de Carvalho' ${ }^{1}$, Antonio Flávio Mídio ${ }^{2 *}$
}

${ }^{1}$ Medicolegal Institute, São Paulo, Forense Toxicology Section, ${ }^{2}$ College of Pharmaceutical Sciences, Toxicology, University of São Paulo.

*Correspondence:

A. F. Midio

Depto. de Análises Clínicas e

Toxicológicas

FCF/USP

Av. Professor Lineu Prestes, 580 05508-900 - São Paulo - SP

Brasil

E-mail: afmidio@usp.br
Street drugs when in great demand in an illicit market become not only more expensive but are also subject to extensive adulteration and dilution. These fraudulent practices may also contribute to the amplification of toxic effects observed in the abuse of certain drugs including cocaine hydrochloride. The number of seizures reflects the increase of illicit use of cocaine powder in the city of S.Paulo, where the identity of the suspected drug is its hydrochloride form. Routine analytical procedures in enforcement laboratories in Brazil now comprise techniques involving thin layer chromatography for presumptive identification of the drug and eventually gas chromatography for its confirmation or quantification whenever required. The determination of cocaine content, adulterants and diluents in street samples is not only of clinical value but also important for enforcement activities, recognition of its geographical distribution and allocation. So, the aim of this study was to continue examining the quality of cocaine hydrochloride in the illicit market of the city of S.Paulo. Cocaine and adulterant contents were determined as well as the identification of several diluents in 389 out of 1958 samples of "white powder" seized in the city of São Paulo. Thin-layer and gas-liquid chromatography (FID) and GC$M S$ were used for the determination of cocaine and adulterant contents. Spot-tests and thin-layer chromatography were the techniques applied for the identification of diluents. The results were as follows: neither cocaine nor adulterants were detected in 17 samples (4.4\%); of all positive samples (95.6\%) for cocaine, $14 \%$ consisted of no more than $200 \mathrm{mg} / \mathrm{g}$; in $70 \%$ cocaine purity ranged from 201 to $550 \mathrm{mg} / \mathrm{g}$ and in $16 \%$ it was not greater than $700 \mathrm{mg} / \mathrm{g}$. The local anesthetics lidocaine and procaine were detected in 19 samples (4,9\%) in a range from 10 to $602 \mathrm{mg} / \mathrm{g}$. Caffeine was present in only two samples (179 and $356 \mathrm{mg} / \mathrm{g}$ ). The main diluents detected were carbonates and bicarbonates (19.2\%); silicates (13.8\%), sugars (9.59\%); starch (5.6\%), borate (3.8\%) and sulphates(2.8\%). Contaminants (secondary products) originated from coca paste refining or decomposition processes were not analysed.
Uniterms:

- Street-drug

- Cocaine hydrochloride content

- Adulterants

- Diluents 


\section{INTRODUCTION}

Street drugs when in great demand in the illicit market of any city in the world become not only more expensive to the user but are also subject to frequent and extensive processes of adulteration and dilution, deliberately undertaken by the dealers with the obvious purpose to increase their profits.

Adulterants are compounds with similar pharmacological, sensorial and physical-chemical properties of the drug to which they are added to simulate its effects. On the other hand diluents are organic or inorganic compounds with no significant pharmacological properties, intentionally added to the street-drug to dilute the active ingredient and increase the volume and weight of the product to be trafficked (Bermejo-Barrera et al.,1999; Shesser et al., 1991).

Cocaine hydrochloride is rarely marketed in its pure form. Besides adulterated and/or diluted it is found in the illicit market naturally contaminated by compounds and/ or impurities originated from the different processes of production (refining) and even hydrolysis (Casale, Waggoner Jr., 1991).

Frequent cocaine hydrochloride adulteration and dilution, besides being fraudulent processes, have also contributed to the amplification of toxic effects observed in cases of abuse specially for those persons whose intakes are up to several grams a day (Midio et al., 2000).

The presence of adulterants and diluents in streetdrug samples is not only of clinical value in evaluating the risk to the users' health but also important for enforcement activities, recognition of the geographical distribution and allocation as well as patterns of use and new tendencies in the traffic activities ( News, 1979; Kozel, Adams, 1985).

Routine analytical procedures in enforcement laboratories now comprise techniques involving thin-layer chromatography for presumptive identification of the drug and some other components of the sample and eventually gas-chromatographic techniques for confirmation or quantification of the drug and adulterants whenever required.

The increase of illicit use of cocaine powder, the primary form of cocaine in use in S. Paulo, the biggest and most important city in Brazil, is expressed by the number of seizures of small containers where the suspected drug is the hydrochloride form.

In the year of 1996, police authorities seized 2105 small packages of "white powder", trafficked in the city of S. Paulo and suspected of being cocaine. Simple qualitative analyses were performed in the routine work of Medicolegal Institute-S.Paulo. However the range of cocaine purity and the presence of pharmacological active adulterants were determined in only 233 samples taken at random. The analyses were performed in our laboratories and the findings were: $3.44 \%$ of the samples were negative for cocaine or any other active substance; $76.82 \%$ were constituted by no more than $300 \mathrm{mg}$ of cocaine/g of powder. Only local anaesthetics (lidocaine and procaine) were found as adulterants in $4.3 \%$ of all samples (Midio et al., 2000).

The aim of this study was to continue examining the quality of cocaine hydrochloride in the illicit market of the city of S. Paulo for the year of 1997 . The contents of cocaine and adulterants as well as the identification of several diluents were determined in 389 out of 1958 samples of "white powder" seized by the police authorities.

\section{MATERIAL AND METHODS}

All the 389 samples taken at random all year long were constituted by portions of $0.1 \mathrm{~g}$ of the white powder which had been previously analysed qualitatively for law enforcement purposes, in the routine work of the laboratories of Medicolegal Institute-S. Paulo. Our analyses were performed at the laboratory of Toxicology, College of Pharmaceutical Sciences, University of S. Paulo.

Samples were screened for cocaine and adulterants using a thin-layer chromatographic (TLC) technique with silicagel 60 plates (Merck). Solvents and chromogenic agents were those ordinarily cited in the literature suitable for detecting cocaine, local anaesthetics and some other central nervous system (CNS) stimulants normally employed for the purpose of cocaine hydrochloride adulteration. TLC also screened sugars according to the literature (ONU, 1994). All gas-chromatographic determinations were performed in a gas chromatograph (Varian 3300 model) equipped with a flame ionization detector (FID), a Varian 4400 Graphic Integrator and a 25m DB-1 (J \& W Scientific) capillary column (0.25-mm internal diameter, 0.25-mm thickness).

Positive samples for adulterants or those samples in which the compounds were not unequivocally detected were submitted to gas-chromatography/mass spectrometry (GC/MS) for confirmation.

Gas-chromatography/mass spectrometry was performed in a DB-5 MS (J \& W Scientific) 30-m capillary column $(0.25 \mathrm{~mm}$ internal diameter, $0.25-\mathrm{mm}$ thickness) and a Finnigan Mat GCQ ion-trap detector (full scan reconstruction ion chromatogram). Results were processed in a Finnigan upgrade data system. 
Standard solutions: cocaine hydrochloride solution (Mallinckrodt) and local anaesthetic solutions (Astra) in methanol. Sugar standards (Merck) in water solutions.

Diluents such as carbonates, bicarbonates, starch, borate, silicates and sulphates were detected using analytical spot tests also described in the literature (Vogel, 1981).

\section{RESULTS AND DISCUSSION}

From January 1 to December 31, 1997 law enforcement agents seized within the city of São Paulo, 1958 small packages of white powder which were qualitatively analysed for cocaine hydrochloride in the government laboratories of Forensic Toxicology, in the city of São Paulo, Brazil.

About $20 \%$ of the seized material (389 samples), taken at random were quantitatively analysed for cocaine hydrochloride and adulterant contents and to identify diluents present in them. The number of samples analysed was statistically large enough to offer presumptive evidence of the quality of cocaine powder marketed in São Paulo City.

Data obtained from the analyses are summarised in Table I and showed in Fig.1.

The analyses were conducted using a combination of techniques: TLC, capillary GC/FID, GC/MS for confirmation whenever necessary as well as spot tests for the detection of several diluents.
TABLE I - Diluents found in 389 illicit cocaine samples seized in the city of S.Paulo, in 1997

\begin{tabular}{lc}
\hline Diluents & \% of the total \\
\hline Carbonates/bicarbonates & 19.3 \\
Silicates & 13.9 \\
Starch & 5.6 \\
Borate & 3.1 \\
Sulphates & 2.8 \\
Sugars (glucose, lactose and sucrose) & 9.6 \\
\hline
\end{tabular}

\section{Cocaine hydrochloride content}

Thin-layer chromatographic analyses performed in all samples showed $95.6 \%$ positive results for cocaine hydrochloride. This figure is very similar to the $96.5 \%$ of positive results found in the samples collected and analysed for the same city in 1996 (Midio et al., 2000).

Analytical results obtained in the 389 samples were gathered in intervals of $50 \mathrm{mg}$ of cocaine/g of powder (Fig.1) and the statistical distribution was studied. The analysis of the graph shows that $70 \%$ of the samples presented cocaine contents in a range of 201 to $550 \mathrm{mg} / \mathrm{g}$ of powder. Both extremities of the curve responded for about $15 \%$ each. An arithmetical mean of $375 \mathrm{mg} / \mathrm{g}$ and a median value of $379 \mathrm{mg} / \mathrm{g}$ suggest a characteristic symmetry of a normal distribution. In a determination of

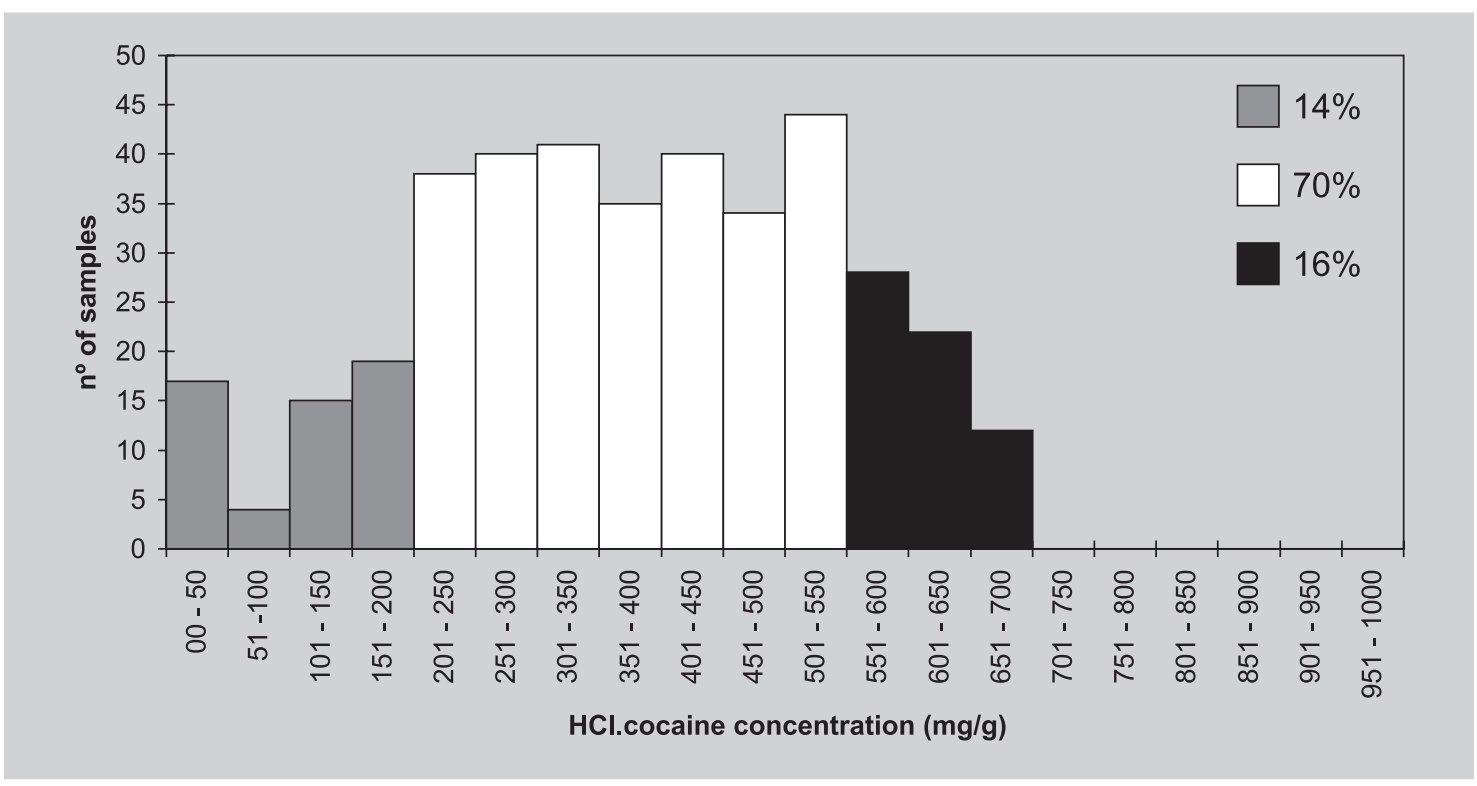

FIGURE 1 - Statistical distribution of cocaine hydrochloride contents ( $\mathrm{mg} / \mathrm{g}$ of powder) in 389 samples seized in the city of São Paulo, SP, Brazil in the year of 1997. 
purity of cocaine in several regions of Spain, from 1985 to 1993, the authors reported to have found normal distributions in various years of seizure (Barrio et al., 1997). Modal interval that corresponds to the maximum frequency was between $501-550 \mathrm{mg} / \mathrm{g}$. Contrarily to the results obtained in our previous study no sample showed cocaine content above $700 \mathrm{mg} / \mathrm{g}$ (Midio et al., 2000).

\section{Adulterant content}

The most common adulterants found in the cocaine samples were lidocaine and procaine (4.9\%) in a range of 10 to $602 \mathrm{mg} / \mathrm{g}$ of powder and caffeine in two samples (179 and $356 \mathrm{mg} / \mathrm{g}$ ). Lidocaine, in spite of its high toxicity, seems to be the most important adulterant in illicit cocaine hydrochloride in Brazil as well as in some other countries, probably in order to simulate cocaine organoleptic characteristics (Fucci, De Giovanni,1998; Gomez, Rodriguez, 1989). In the samples analysed in S.Paulo, in 1996, lidocaine (3.5\%) was also the most frequent adulterant followed by procaine (1.0\%) (Midio et al., 2000).

\section{Diluents}

The most common diluents were found in $44 \%$ of all samples analysed and are presented in Table I. Some samples contained besides cocaine hydrochloride mixtures of adulterants and different types of diluents.

According to the Division of Narcotics of the United Nations only four diluents (sugars, borate, bicarbonates and starch) are indicated to be analysed in the evaluation of street drug samples (ONU,1994).

Among different sugars, glucose, lactose as well as mannitol are the most frequently found (Fucci, De Giovanni,1998; Gomez, Rodriguez, 1989; LopezArtiguez et al., 1950.

To our knowledge no diluents were ever analysed before in street drug samples in South America. Unidentified compounds in $56 \%$ of the samples should be expect to be constituted by other alkaloids naturally present in coca leaves (ecgoninemethylester, tropacocaine, cynamoil cocaine, etc) or products of decomposition (hydrolysis) derived from production, refining and storage (benzoic acid, anhydrous ecgonine, norcocaine, etc).

The study of the components of a street drug is extremely important since it can help to obtain useful information about the frequent changes in the illicit market, characterise the drug, put forward consideration on toxicological vigilance and facilitate the correlation between drug and causa mortis.

\section{RESUMO}

\section{Qualidade da cocaína traficada em 1997 na cidade de São Paulo, Brasil}

Teores de cocaina e adulterantes bem como vários diluentes foram determinados em 389 amostras de pó branco apreendidas na cidade de São Paulo, no ano de 1997. Cocaina e seus adulterantes foram analisados por cromatografia em camada delgada, cromatografia em fase gasosa (detetor de ionização de chama) e cromatografia em fase gasosa acoplado a espectrometria de massa $(C G / M S)$. Diluentes foram analisados através de "spot tests" e da cromatografia em camada delgada. Foram obtidos os seguintes resultados: em 4,4\% das amostras não foram detectados cocaína e adulterantes; de todas as amostras positivas para cocaina, 14\% não continham mais que $200 \mathrm{mg} / \mathrm{g}$ de pó; em $70 \%$ a pureza da cocaina variou de 201 a $550 \mathrm{mg} / \mathrm{g}$ e em 16\% não foi maior que $700 \mathrm{mg} / \mathrm{g}$. Os anestésicos locais lidocaina e procaina foram detectados em 19 amostras em concentrações que variaram de 10 a $602 \mathrm{mg} / \mathrm{g}$ de pó. Cafeína foi encontrada em duas amostras. Os principais diluentes detectados foram: carbonatos e bicarbonatos, silicatos, açúcares, amido, borato e sulfatos. Contaminantes (produtos secundários) originários do refino da pasta de coca ou de processos de decomposição não foram analisados.

UNITERMOS: Cocaína. Droga de rua. Adulterantes. Diluentes.

\section{REFERENCES}

BARRIO, G.; SAVEDRA, P.; LA FUENTE, L.; ROYUELA, L. Purity of cocaine seized in Spain,19851993: variations by weight, province and year of seizure. Forensic Sci. Int., Lausanne, v.85, p. 15-28, 1997.

BERMEJO-BARRERA, P.; MOREDA-PIÑERO, A.; MOREDA-PIÑERO, J.; BERMEJO-BARRERA, A.;BERMEJO-BARRERA, A. M. A study of illicit cocaine seizure classification by pattern recognition techniques applied to metal data. J. Forensic Sci., Philadelphia, v.44, p. 270-275, 1999

CASALE, J. F.; WAGGONER JUNIOR, R .J. A chromatographic impurity signature profile analysis for cocaine using capillary gas chromatography. J. Forensic Sci., Philadelphia, v.36, p.1312-1330,1991. 
FUCCI, N.; DE GIOVANNI, N. Adulterants encountered in the illicit cocaine market. Forensic Sci.Int , Lausanne, v. 95, p. 247-252, 1998.

GOMEZ, R.; RODRIGUEZ, A. An evaluation of the results of a drug sample analysis. Bull. Narc., New York, v.41, p.121-26, 1989.

KOZEL, N. J.; ADAMS, E. H. Cocaine use in America. Epidemiological and clinical perspective. Rockville: National Institute of Drug Abuse, 1985. 54 p. [Research Monograph. No 61].

LÓPEZ-ARTÍGUEZ, M.; CAMEÁN, A.; REPETTO, M. Unequivocal identification of several common adulterants and diluents in street samples of cocaine by infrared spectroscopy. J. Forensic Sci., Philadelphia, v. 40, p. 602-610, 1995.

MIDIO, A. F.; SILVA, O. A.; BEI, M. C.; .LIMA, I. V. Cocaine content and adulterants in street samples seized in the city of S. Paulo, Brazil. Rev. Bras. Cienc. Farm., São Paulo, v. 36, p. 249-251, 2000.
The 1977 street drug analysis results. Clin. Toxicol., New York, v.14, p.619-630, 1979. [NEWS].

ORGANIZACIÓN DE LAS NACIONES UNIDAS. Laboratorio de toxicología y química legal del cuerpo médico forense del poder judicial de la nación. Identificación y análisis de drogas de uso indebido: manual para el curso de entrenamiento básico del personal de laboratórios forenses. Buenos Aires: ONU, 1994. s.p. (Manuales ST/NAR/7 y 13 de las Naciones Unidas.Productos de Coca).

SHESSER, R.; JOTTE, R.; OLSHAKER, J. The contribution of impurities to the acute morbidity of illegal drug use. Ann. Emerg. Med., Lansing, v.9, p.336-342,1991.

VOGEL, A. I.Química analitica qualitativa. 9. ed. São Paulo: Mestre Jou, 1981. 665p.

Recebido para publicação em 08 de agosto de 2002. 